\title{
El desfile de las bifurcaciones
}

\section{Heber Quijano}

$\mathrm{E}$

1 circo es un museo de nuestro asombro, me decían al unísono mis abuelos mientras arreaban a los elefantes de dos trompas por un costado del herpetario donde las serpientes bicéfalas acechaban a los ratones. Mi abuelo Chang disfrutaba verlos beber agua fresca, y mi abuelo Eng, hablarles como si estuvieran en una cantina. Los elefantes tienen buena memoria, decía. Mi hermano y yo nos divertíamos apostando cosas sin importancia para atinar cuánto tardarían las serpientes en devorar a los ratones aterrados ante dos fauces. Pero nada nos asombraba más que su cambio de piel la luna llena previa al equinoccio de primavera.

Mis abuelos Chang y Eng estaban unidos a un mismo cuerpo por el esternón, el hígado y un cartílago. Fueron llamados así en honor a esos hermanos de Samut Songkhram, nacidos el día de san Evelio, el consejero de Nerón torturado en la torre de Pisa. Eso decían al señalar con su mano de tres dedos el viejo libro The Two Siamese Twins, escrito por los siameses Irving y Emil Wallace. 
Sin embargo, preferían lecturas sobre la alquimia emocional del circo, las transformaciones provocadas por los espectáculos, la catarsis del asombro, más que sobre las acrobacias y los viejos ritos paganos. Los lunes, único día de descanso, discutían nuevas propuestas para el circo mientras disfrutaban su almuerzo. Seguía la polémica con el café turco y luego las sacudidas y las amenazas. ¿Cómo pueden golpearse dos personas que comparten el mismo cuerpo? Hasta que la abuela Grace les gritaba «quietos». Después venía el vino y la creciente algarabía de la ebriedad.

Así, mi hermano y yo atestiguamos por años su malicia para lucrar con el asombro mediante propuestas para dinamitar el anillo inventado en Londres por Philip Astley, para enardecer a los animales, para superar las acrobacias rusas y francesas, para sublimar los prodigios y deformidades del cuerpo, como el síndrome de Proteo del inglés Joseph, Hombre Elefante, Merrick o la hipertricosis de la mexicana Julia Pastrana, sin mencionar el espectáculo prohibido de las excentricidades eróticas, del que nadie hablaba pero del que más se lucraba.

Mientras regaban el bonsái y el solimansté, sus hijos Janos y Abraxas nos presumían que los abuelos conquistaron a la única miss Universo públicamente recluida por bipolaridad: Grace Monroe, su madre. La californiana veneraba la alquimia, el hermetismo y la mitología. Quizá por ello, esos tres espíritus (aunque bien podríamos decir cuatro) confluyeron en un siniestro y sublime deseo erótico. Chang y Eng se ahorraron los problemas domésticos que sí tuvieron los siameses primigenios al casarse en Carolina del Norte con distintas mujeres.

Nuestro circo era famoso por el diamante fraguado por Jill Magid con las cenizas de Luis Barragán; por el tegu blanquinegro de la Amazonía que no reconocía el rigor mortis de su hembra disecada, que ante su fracaso amoroso aullaba como lobo en celo. En los lugares montañosos admiraban nuestros árboles «mágicos»: el bonsái que estrangula, seca y truena los arboles vecinos, y el solimansté, del que nacen hormigas con cola de alacrán. En los lugares cálidos, triunfaban los elefantes de dos trompas, las serpientes bicéfalas y los cancerberos.

Pero el clímax era la narración oral de la historia del circo, teatralizada por mis abuelos, como un conjuro chamánico, con los efectos aromáticos de los girasoles bicípites que aprendimos a sembrar y cosechar cuando fuimos a Fukushima. Todas las historias tienen un efecto hipnotizador, decían Chang y Eng. Con ese eco particular generado por dos voces en un mismo cuerpo, la gente callaba, concentrada en el poder evocador de sus palabras. Con un histrionismo nato y la seducción de los estafadores, ambos gritaban una invocación sagrada en chino, arameo, náhuatl, navajo y guaraní: «nuestro miedo es un museo, es un circo, es un espejo», mientras las luces los iluminaban y el público descubría a los siameses y se estremecía en un silencio parecido a la revelación sagrada de un sacrificio secreto y subterráneo. Entonces, el 
público se tocaba inmediatamente después de esa frase sentenciosa y lapidaria con que aparecían mis abuelos en el centro de la pista. Se tocaban el pecho, la boca, los ojos; se palpaban el rostro como si descubrieran algo nuevo o confirmaran que no habían perdido nada... Y tocaban en el hombro a su acompañante, en una aceptación cómplice del suceso.

Hasta que una noche de otoño, ante la revelación de los siameses, una niña de Zagarramurdi se convulsionó hasta el infarto. Casi inmediatamente vinieron los reportajes, la infamia y la lucha de nuestro espectáculo contra el morbo siniestro provocado por los medios. Luego supimos la desgracia: la metástasis de la abuela Grace, seguida de la convalecencia de nuestros padres Janos y Abraxas.

El cuerpo es un universo, decían mis abuelos al unísono. Nunca está quieto, siempre se despliega y crece, afirmaba Eng con la fuerza espiritual de sus setenta años y el brazo moviéndose con las palpitaciones involuntarias del párkinson, mientras mi hermano y yo echábamos la última paletada de tierra, justo en la víspera del equinoccio de primavera.

Nuestra madre no supo lidiar con la herencia de Grace de cuidar a los abuelos, cada vez más irritables y agresivos. Tampoco supo asimilar la soledad de su cama. Se deshojó al siguiente invierno. Se marchitaron los bonsáis del ficus y del solimansté, probablemente porque ya no recibían agua de los siameses Janos y Abraxas.

Mis abuelos se hacían los fuertes, los muy hombres, los pilares de todo el circo. Y lo eran. Pero ya nada era igual sin Grace, sin sus hijos y con una empresa a la que empezaba a escasearle el público y el dinero. Mi hermano y yo no podíamos ponernos de acuerdo para solicitarles las riendas del circo. Ya no éramos unos niños y los abuelos no habían entendido que ya estaban viejos, cansados y tercos ante el cambio en las expectativas del público.

Eng empezó a beber de más, sin importarle ya las conversaciones con Chang en el almuerzo de los lunes, ni el destino de las arcas del circo, ni la pastura de los elefantes con dos trompas, ni los ratones para las serpientes. Aquel 10 de mayo, mi hermano y yo no supimos cómo cancelar el acto principal. El abuelo Eng estaba tan borracho que impedía a Chang mantenerse en pie, por lo que no pudimos cumplir la propuesta de matrimonio contratada y pagada por Irving y Emil a la madre de sus hijos gemelos, Julia. La demanda arrasó nuestros ahorros.

Quizá por cansancio o fastidio, Chang amaneció muerto el 11 de mayo. Su cuerpo se había convertido en una masa difícil de levantar. Con resaca y devastado por la muerte de su hermano, el abuelo Eng no supo reaccionar. No tuvimos otra opción. Le apretamos el cuello con toda nuestra fuerza. Empujé los seis dedos de la mano derecha contra los tres de la izquierda para destrozarle el gañote, para que no sufriera la ausencia de Chang, para que no padeciera las convulsiones del párkinson, para que 
no supiera que los circos eran ya fantasmas, reliquias, museos de otro tiempo..., para que callara que el asombro no escondía inocencia sino engaño, malicia, perversión.

Cuando las venas de Eng dejaron de palpitar en nuestras manos, mi hermano se acobardó, titubeó al ver sin mirada los ojos del abuelo, se pasmó como un colibrí inmóvil en el aire. Sus sollozos eran cobardes y sin sentido. Tuve que dispararle. iQué difícil usar una pistola con tres dedos! Ahora tengo que cortarlo de mi cartílago. Quedarme con nuestro hígado y nuestro esternón, pero temo no poder cauterizar la herida. Temo que nos desangremos. Y los elefantes no nos recuerden. Y beban nuestra sangre con sus dos trompas, como dos ebrios en una cantina.

Heber Quijano. Maestro en Humanidades y licenciado en Letras Latinoamericanas por la Universidad Autónoma del Estado de México (UAEM), México. Recibió el Premio Internacional de Poesía Gilberto Owen Estrada 2006, así como la Presea Metepec y la beca FOCAEM en 2014. Ha publicado cuatro poemarios, cuatro pliegos de poesía y distintos poemas, cuentos, reseñas, artículos académicos y capítulos de libros en distintas revistas académicas y literarias. Ha participado en festivales culturales, ferias de libro y eventos académicos nacionales e internacionales. Es columnista de Criterio Noticias (Uni Radio 99.7 FM) y docente en la Facultad de Humanidades de la UAEM. 